\title{
Opioid Receptor Binding
}

National Cancer Institute

\section{Source}

National Cancer Institute. Opioid Receptor Binding. NCI Thesaurus. Code C40525.

A process that involves the non-covalent binding of opioids to one of four opioid

receptors. These interactions are involved in mediation of analgesia, euphoria, and physical dependence to opioids. 